\title{
Correction: correlations between carotid plaque progression and mechanical stresses change sign over time: a patient follow up study using MRI and 3D FSI models
}

Dalin Tang ${ }^{1,2^{*}}$, Chun Yang ${ }^{2,3}$, Gador Canton ${ }^{4}$, Zheyang $\mathrm{Wu}^{2}$, Thomas Hatsukami ${ }^{5}$ and Chun Yuan ${ }^{6}$

\author{
* Correspondence: dtang@wpi.edu \\ ${ }^{1}$ School of Biological Sciences and \\ Medical Engineering, Southeast \\ University, Nanjing, China \\ ${ }^{2}$ Mathematical Sciences \\ Department, Worcester Polytechnic \\ Institute, 100 Institute Road, \\ Worcester, MA 01609, USA \\ Full list of author information is \\ available at the end of the article
}

\section{Correction}

After publication of this work [1], it was brought to our attention that the National Sciences Foundation of China grant number stated in the Acknowledgements was incorrect. This work was funded by National Sciences Foundation of China grant 11171030. We apologise for any inconvenience caused.

\section{Author details}

${ }^{1}$ School of Biological Sciences and Medical Engineering, Southeast University, Nanjing, China. ${ }^{2}$ Mathematical Sciences Department, Worcester Polytechnic Institute, 100 Institute Road, Worcester, MA 01609, USA. ${ }^{3}$ China United Network Communications Co., Ltd, Beijing, China. ${ }^{4}$ Department of Mechanical Engineering, University of Washington, Seattle, WA 98195, USA. ${ }^{5}$ Division of Vascular Surgery, University of Washington, Seattle, WA 98195, USA. ${ }^{6}$ Department of Radiology, University of Washington, Seattle, WA 98195, USA.

Received: 27 November 2013 Accepted: 2 December 2013

Published: 5 December 2013

\section{Reference}

1. Tang D, Yang C, Canton G, Wu Z, Hatsukami T, Yuan C: Correlations between carotid plaque progression and mechanical stresses change sign over time: a patient follow up study using MRI and 3D FSI models. BioMedical Engineering OnLine 2013, 12:105.

doi:10.1186/1475-925X-12-126

Cite this article as: Tang et al:: Correction: correlations between carotid plaque progression and mechanical stresses change sign over time: a patient follow up study using MRI and 3D FSI models. BioMedical Engineering OnLine 2013 12:126.

\section{Submit your next manuscript to BioMed Central and take full advantage of: \\ - Convenient online submission \\ - Thorough peer review \\ - No space constraints or color figure charges \\ - Immediate publication on acceptance \\ - Inclusion in PubMed, CAS, Scopus and Google Scholar \\ - Research which is freely available for redistribution \\ Submit your manuscript at \\ www.biomedcentral.com/submit \\ C Biomed Central}

(c) 2013 Tang et al.; licensee BioMed Central Ltd. This is an Open Access article distributed under the terms of the Creative Commons Attribution License (http://creativecommons.org/licenses/by/2.0), which permits unrestricted use, distribution, and reproduction in any medium, provided the original work is properly cited. The Creative Commons Public Domain Dedication waiver (http://creativecommons.org/publicdomain/zero/1.0/) applies to the data made available in this article, unless otherwise stated. 